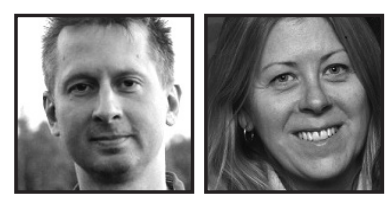

\title{
Literacies, Leadership, and Inclusive Education: Socially Just Arts-Informed Eco-Justice Pedagogy
}

\author{
Andrejs Kulnieks, York University \\ Kelly Young, Trent University
}

\begin{abstract}
In this article we outline the primary tasks of eco-justice education with a focus on identifying diverse cultural methods for understanding inclusion both theoretically and in educational practices. Eco-justice education involves a critical cultural and linguistic analysis of the interrelatedness of the social and ecological crises. It is through artsinformed eco-justice education practices that we are able to outline the importance of the benefits of dwelling in a learning garden. We offer specific examples of how to enact an eco-justice education curriculum in order to foster the development of eco-social inclusive habits of mind in teacher education.
\end{abstract}

\section{Introduction}

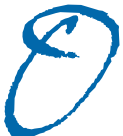

ur article emerges from several knowledge sources as both authors have been working together for over a decade, bringing together an interdisciplinary focus to fostering socially just arts-informed environmental education. The authors have worked with learners at all levels $(\mathrm{K}-\mathrm{PhD})$ and are teacher educators who have spent many years making links between theory and practice in order to promote education that removes barriers to environmental education, and inspires teachers to explore an integrated and inclusive approach to social and environmental learning across the curriculum. Our research question, "Why is poetic inquiry important?" leads us to an intention of our research and teaching, which is to bring a socially just ecological perspective into teacher education curriculum. Poetic inquiry provides 
an opportunity for writers to engage their own identities through focal practices as outlined by Borgmann (1992), Sumara (1995), and Kulnieks, Longboat, \& Young (2010), in an effort to develop a deeper relationship with places and experiences. With this desire to integrate comes a hope that arts-informed eco-justice education will foster inclusive education.

From the early 17th century Latin inclusio(n-), from includere (shut in), inclusion is defined as "the action or state of including or of being included within a group or structure" or "a person or thing that is included within a whole" (OED online). When we refer to inclusion, we consider hierarchies or "isms" such as anthropocentrism (human centeredness), androcentrism (male centeredness), ethnocentrism (ethnic centeredness), ableism (ability centeredness), and so forth. These hierarchies are framed through mechanistic hierarchical language that can perpetuate inequities through exclusionary practices (Bowers, 2002, 2006, 2011; Martusewicz, Edmundson, \& Lupinacci, 2011). It is with an understanding of inclusion as "a person or thing that is included within a whole" (OED online)-meaning that all persons are included in a place-an ecosystem -in its broadest sense, that we propose inclusion to incorporate learning gardens in educational research and practice.

What follows is an overview of eco-justice education (EJE) with an emphasis on arts-informed educational practices in the context of a learning garden program. In the context of this article, our arts-informed practices involve poetry as the art that is used in our curriculum. We bring forth a framework that includes an excerpt from an environmental autobiography (Young, 2006) that traces early memories of childhood learning and playing in the natural world, and two poems, Granny (Young, 2014) and Icy Daze (Kulnieks, 2014) about intergenerational knowledge and food sustainability, as we frame an approach to inclusive education.

\section{Eco-Justice Education}

EJE involves two primary tasks. The first task entails a critical cultural and linguistic analysis of the ecological and social crises-as inextricably linked-through a critique of modernism, local-global and scientific-technological perspectives, and the mechanistic nature of root metaphors that frame language and perception (Bowers, 2002, 2006, 2011; Martusewicz et al., 2011). For example, in order to help learners engage in a deeper understanding of inclusion, we would include an overview of how ecosystems are under increasing pressure to sustain human life; sustainability of food growth and access to clean water continue to become more and more scarce, and as a result, social inequities will become more and more prevalent. In addition, we consider 
how culture and language separates humans from the natural world and leads to the loss of biodiversity that all life depends on.

While much time can be spent on elaborating how humans got to the place where the natural world is being undermined, what we focus on is that regardless of race, class, gender, or abilities, we are all sustained and interconnected with a local eco-system. Inclusion involves all living things. By framing our current social and ecological realities at the outset, we move toward the second task of EJE that involves identifying diverse cultural methods for possible activism through an analysis of the local environment, identifying non-monetized relationships, place-based learning, and an integration of intergenerational knowledge (Bowers, 2002, 2006, 2011; Martusewicz et al., 2011). EJE provides an array of cultural methods for understanding inclusive education involving socially just ecological perspectives and practices. We believe that an artsinformed curriculum can connect learners with natural landscapes by broadening an understanding of inclusive education and enhancing eco-social literacy perspectives. We accomplish this second task by elaborating on the connection between stories, poetry, and a broader understanding of inclusion through a learning garden alternative practicum program.

\section{Arts-Informed Eco-Justice Education Through Environmental Autobiography and Poetry in a Learning Garden Program}

As they design their own garden beds, students begin to fit plants and life cycles into the context of place. (Williams \& Brown, 2012, p. 32)

The Learning Garden: In 2012, a learning garden alternative practicum was introduced in an already established teacher education program, alongside an Eco-Mentorship Program. The framework of the learning garden was informed by Williams and Brown (2012) who have noted: "The learning gardens provide comprehensive, experiential, and transformative experiences to students creating a grounded sense of place before they can truly become stewards of the land" (p. 32).

Through the learning garden we explore our own relationships with place and we learn about intergenerational knowledge, sustainable food systems, and local and global relationships. Teacher candidates work together and are engaged in planting activities as they prepare to enter local K-12 classrooms to help foster learning gardens. The gardening practices are accompanied by arts-informed writing activities. For example, students are asked to remember their earliest memories of their engagement 


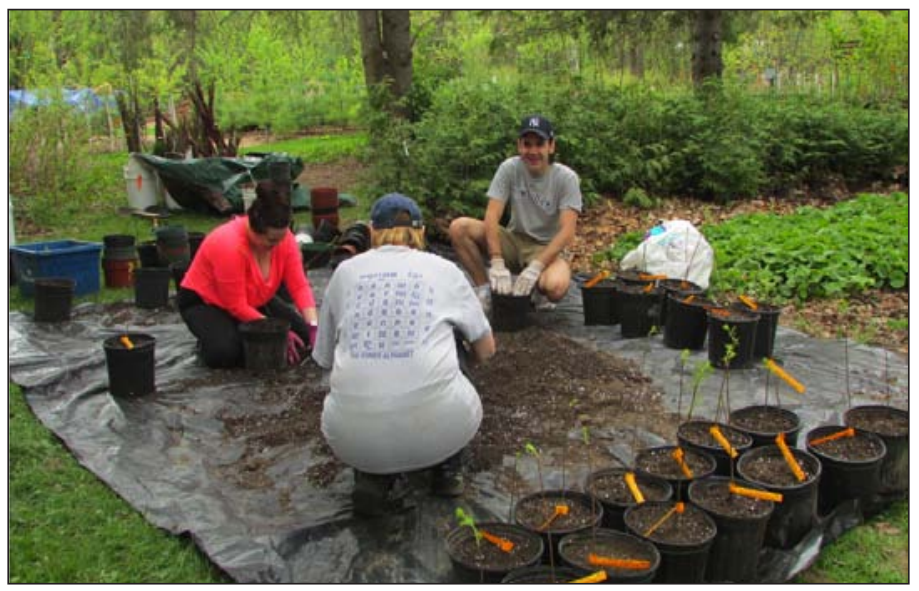

Fig. 1: Learning garden 2013

with/in the natural world. In the following section we have chosen an excerpt from an environmental autobiography that provides an example of lived experiences of the development of a relationship with the natural world. These narratives also reveal the development of ecological habits of mind. Initially, we draw upon experiences of childhood playing in the natural world. The autobiographical excerpt informs an understanding of the ways inclusive education involves learning from a place.

\section{Excerpt From an Environmental Autobiography}

The role of the imagination is not to resolve, not to point the way, not to improve. It is to awaken, to disclose the ordinarily unseen, unheard and unexpected. (Greene, 1995, p. 28)

A special place that my friends and I liked to visit was Dylan Woods located in Rosemère, Laval, Québec near the Laurentian Mountains. We were all the same age and we were connected to our ways of knowing and ways of being in natural landscapes through our daily practices of playing in the woods. The woods had a golf course backing on to one side and a swamp at the other. Once inside the bush, there were paths that found us. We had to pay attention to our surroundings in the swamp because the swamp was alive and it was expected of us. We all knew this and were always aware while we walked through the bog. Understanding the significance of natural places came easy as a child as we had a real respect for where we explored. The walk through the woods was magical because everything was alive. We crossed logs and wet moss and knew our way to the special place deep inside the forest. The branches that we held onto in order to cross over into the swamp were known by heart. Once you got to the large stump you had to go left and bend under the large 
branch that had fallen over. Inside the special place you could see all of the logs in a circle. One log had a very large hollow stump behind it in a sort of podium fashion. When we stood on the logs in a round circle we were surrounding quicksand. There was an opening to the sky through the evergreens that let in a stream of sunshine, making the area surprisingly bright in contrast with the rest of the swamp. The bog was so thick that it was hard to tell at times where the quicksand began and ended. (Young, 2006, pp. 39-40)

The environmental autobiographical excerpt that we chose reveals a mythical place where children ran free and played and learned about natural landscapes, evading what Louv (2008) terms nature deficit disorder. As Cooper (1978), Hester, (1985), and Wyman (1987) outline, environmental autobiography is an essential aspect of environmental education. Through environmental autobiography deep relationships can be formed between language and landscape (Kulnieks, 2009; Young, 2006). These relationships are what we refer to as ecohermeneutic in nature because they trace language rearward beyond their first usage and back to the Earth (Kulnieks, Longboat \& Young, 2010). Through environmental autobiography, the writer is focused on places where she and her friends had meaningful engagements with intact ecosystems. These encounters serve as a way to shift from a place that Borgmann (1992) refers to as "hyper-reality," to activities that fostered connections with local places.

A further dimension of environmental autobiography is moving towards exploring how to represent ideas through a process of poetic inquiry. The process of poetic inquiry that we engaged in involves writing through the senses. If possible, our writing process takes place outdoors beside a garden where there are trees and wildlife. We write with our students and engage in the poetry process together. Beginning with a period of mediation to clear all thoughts from our mind, we focus on one special place that holds within it special memories. By dwelling on this place, we spend time imaging it through the senses and ruminate about what it felt like, looked like, smelled like, tasted like, and what sounds are evoked by this memory. As the senses are evoked, the writing process begins whereby we "free write," keeping the flow of the writing moving in order to capture all of the senses involved in the memory. We then spend time reworking the initial piece of writing through a step-by-step process. First we remove conjunctions, prepositions, and pronouns, which leaves nouns, adjectives, and verbs. The remaining prose is rearranged into a more poetic form by inserting punctuation if need be. The process of moving from a long piece of prose to a poem often involves several steps, as mentioned above, and involves several drafts. The following poem, entitled Granny, outlines and describes interconnectedness with local landscapes and the importance of intergenerational knowledge. 


\section{Granny}

Harvest time in 1935-

after dog days of summer

harried grandmother stands patiently

bare feet in the farmhouse kitchen

next to the wood stove

watches the garden grow

round hips cling her dress like early ripened fruit

she never tires of her care giving

fragrance of boiling apples

everything is a verb:

tilling, planting, growing,

watering, picking, peeling,

pickling, jarring

all to the rise and fall of bird song melody

a beat, a rhythm to work by

kneeling down to the soil she watches them grow

not simply delicacies

but her muse

a deep love of living things

(Young, 2014)

From this poem, our understanding of diversity and inclusion as necessary for survival, and the true nature of interconnectedness of all living things, develops as we are reminded that we learned from elders who had meaningful relationships to natural landscapes. This poem reminds us of the importance of learning to understand and to participate in healthy focal activities like growing, collecting, and preparing foods. These activities inspired an understanding that food does not come from a grocery store as we closely watched the rhythm of the seasons: planting-growing-harvestingpreserving and conserving. It was taken for granted that an important part of life included sustainable practices. For Gregory Cajete (1994), "Art, as a human thinking and expressing process, is intimately connected to the creative explosion of human consciousness" (p. 153). As we engage in writing activities that bring memories and 
landscape together, as in the excerpt from the environmental autobiography or in the poem Granny, we are learning through poetic inquiry. Solnit (2000) writes:

To walk the same route again can mean to think the same thoughts again, as though thoughts and ideas were indeed fixed objects in a landscape one need only know how to travel through. In this way, walking is reading, even when both the walking and reading are imaginary, and the landscape of the memory becomes a text as stable as that to be found in the garden, the labyrinth, or the stations. (p. 77)

Solnit's work, Wanderlust, highlights the importance of understanding relationships between memory and landscape as inclusionary practices. Walking the land is an essential part of knowing it. Moving beyond buildings to consider the things humanity depends on for survival becomes part of a learning process essential for fostering a love for the gifts that the earth provides. The following poem takes up Solnit's (2000) understanding that memory requires landscape. It is part of the author's inquiry about our dependency upon the global economy and the importance of local sustainable food.

\section{Ice daze}

boiling water becomes snow

thrown into the air this last working day of the year

memories warm you over hand-picked wild rice, beef, garlic and mushroom gravy cherished in time with friends who left us long ago

missed as we walk paths into future journeys

new decades did not override

grandmother's treats from the kitchen or

grandfather's instructions that emerge from rocks and trees

persistence to find our way through weather-born calamities

fishing and hunting focal practices you could not cease

breeze moves through maple-leafed symbol of coming together

extended outdoor activities revitalized for weeks illuminates the storm's power branches and electrical wires layered with ice

still

crash into frozen ground

how do we make warmth and light?

focus echoes throughout the city 
electricity failures extend for days

witness hotels and restaurants closed as pipes begin freeze

no time to ruminate over survival skills

too late to learn what we need to know

search for fruit picked, dried and canned in sun-lit rays

primordial instincts re-kindled

sounds of wind permeate the distant hum of generators

stars visible in crisp darkness clarifies deep dependencies

time and space reconciled

how far have we travelled

beyond remembered tangerine glow of sunrises past

woodshed near the hand-dug basement housed in earth

stocked with winter provisions

families reliant on each other to keep warm and nourished

(Kulnieks, 2014)

The above poem illustrates how a return to particular places and events over a course of time becomes a rumination of our interconnectedness to our local landscapes. It is through poetic inquiry that we can consider what is really important. For example, topics such as food, shelter, and basic survival reveal the importance of understanding intergenerational knowledge that is passed down from elders. In "Original Instructions," Nelson (2008) outlines the importance of healthy ways of eating through practices like "slow food." The poem reminds us of the importance of taking a few steps back from the way things are. It is important to consider what John Mohawk (Nelson, 2008) and Indigenous thinkers around the world remind us, that food should be understood as medicine. This clearly goes against language and imagery that suggest that food is fuel.

With an increasing reliance on individualism and consumerism over the significance of community and local ecosystems, it becomes necessary to engage students in EJE practices that foster eco-social inclusive habits of mind. In Rebels against the future: The Luddites and their war on the industrial revolution, Kirkpatrick Sale (1995) explores how the global industrial consumer-dependent system of production trumps local culture. He writes:

All that 'community' implies—self-sufficiency, mutual aid, morality in the market place, stubborn tradition, regulation by custom, organic knowledge instead of 
mechanistic science-had to be steadily and systematically disrupted and displaced. All the practices that kept the individual from being a consumer had to be done away with so that the cogs and wheels of an unfettered machine called the 'economy' could operate with interference, influenced merely by invisible hands and inevitable balances. (p. 38)

Sale suggests that with the increased dependency on the global economy comes a destruction of different forms of intergenerational knowledge, and all of the expertise required to sustain healthy relationships with local environments. He understands that marginalized groups are the most vulnerable in society that blindly support consumerdependent lives. Socially just inclusive education needs to include an understanding of bioregionalism and the necessity of interrelationships with local ecosystems.

\section{Conclusion}

There are many ways that educators can inspire creative ways of thinking about the challenges we will all face in the future. Arts-informed curriculum can inspire a dialogue between socially just and ecologically minded theorists about how to develop inclusive curriculum. Educators should consider what they can infuse into the curriculum to prepare students for the future. In light of recent ice storms, heavy winter weather, and power outages that last increasingly lengthy periods of time, it is important to help students think about how they will prepare for similar situations. As Kulnieks' poem alludes to, we do not know when we will be faced with situations beyond our control. Art-whether through painting, photography, or poetic inquiry-provides an opportunity to explore possibilities that are student-centered, student-motivated, and inspired.

Poetic inquiry can provide spaces to consider what is at the heart of student thinking and to develop knowledge about local landscapes. It is important for learners to have an opportunity to create and engage with activities that will sustain them in the years beyond their immersion in public systems of education. Ultimately, through poetic inquiry and engagement in learning gardens we believe that an arts-informed curriculum can inspire a dialogue about inclusive education that involves an analysis of the interconnectedness between social and ecological inequities that continue to grow in the 21st century. Arts-informed practices can provide an opportunity to explore ecosocially inclusive habits of mind that are essential for healthy ways of preparing for the future. 


\section{References}

Borgmann, A. (1992). Crossing the postmodern divide. Chicago: University of Chicago Press.

Bowers, C. A. (2002). Toward an eco-justice pedagogy. Environmental Education Research, 8(1), 21-34.

Bowers, C. A. (2006). Revitalizing the commons: Cultural and educational sites of resistance and affirmation. Langham, MA: Lexington Books.

Bowers, C. A. (2011). Perspectives on the ideas of Gregory Bateson: Ecological intelligence and educational reforms. Eugene Oregon: EcoJustice Press.

Cajete, G. (1994). Look to the mountain: An ecology of Indigenous education. Skyland, NC: Kivaki Press.

Cooper, M. (1978). Remembrance of landscapes past. Landscapes, 22(3), 35-43.

Dooling, D. M., \& Jordan-Smith, P. (Eds.). (1989). I become part of it. Sacred dimension in Native American life. San Francisco: Harper Collins.

Greene, M. (1995). Releasing the imagination: Essays on education, the arts, and social change. Hoboken, NJ: Jossey-Bass.

Hester, R. (1985). Subconscious landscapes of the heart. Places, 10-22.

Kulnieks, A. (2009). Ecopoetics and the epistemology of landscape: Interpreting indigenous and Latvian ancestral ontologies. Unpublished doctoral dissertation, York University, Toronto, Ontario, Canada.

Kulnieks, A. (2014). "Ice daze". In Walking landscapes of story (p. 25). Unpublished poetry manuscript.

Kulnieks, A., Longboat, D., \& Young, K. (2010). Re-indigenizing learning: An eco-hermeneutic approach to curriculum. AlterNative: An International Journal of Indigenous Peoples, 6(1), 15-24.

Louv, R. (2008). Last child in the woods: Saving our children from nature-deficit disorder. New York: Algonquin Books of Chapel Hill.
Martusewicz, R., Edmundson, J., \& Lupinacci, J. (2011). Ecojustice education: Toward diverse, democratic, and sustainable communities. New York: Routledge.

Nelson, M. (Ed.) (2008). Original Instructions: Indigenous teachings for a sustainable future. Rochester, Vermont. Bear \& Company.

OED. (2008). The Oxford English dictionary. Retrieved from: http://www.britannica.com /EBchecked/topic/436518/The-Oxford -English-Dictionary

Sale, K. (1995). Dwellers in the land. San Francisco: Sierra Club.

Solnit, R. (2000) Wanderlust: A history of walking. New York: Penguin Books

Sumara, D. (1995). Response to reading as a focal practice. English Quarterly, 28(1), 18-26.

Williams, D., \& Brown, J. (2012). Learning gardens and sustainability education: Bringing life to schools and schools to life. New York: Routledge.

Wyman, M. (1987). Writing an environmental autobiography: An exercise in understanding environmental values. Paper presented at the North American Association for Environmental Education conference: Excellence in Environmental Education: Gaining Momentum for the Challenge Ahead, Ohio.

Young, K. (2006). Girls of the empire: The origins of environmental education and the contest for Brownies and Girl Guides. Unpublished doctoral dissertation, York University, Toronto, Ontario, Canada.

Young, K. (2014). "Granny". In Vistas: An ecology of landscape. Unpublished poetry manuscript. 


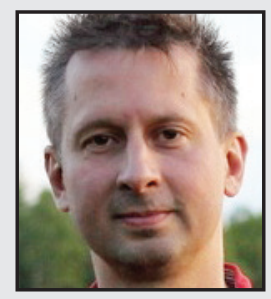

Andrejs Kulnieks teaches at York University's Graduate Studies Program in Education and has developed courses about literacy and society, critical pedagogies, language arts, curriculum methods, and education and schooling. His research interests include curriculum theory, language and literacies, arts-informed research, poetic inquiry, Indigenous knowledges and leadership in eco-justice environmental education. Some of his most recent work can be found in the Canadian Journal of Environmental Studies (CJEE), First Nations Perspectives - The Journal of the Manitoba First Nations Education Resource Centre and a co-edited book: Contemporary Studies in Environmental and Indigenous Pedagogies: A Curricula of Stories and Place.

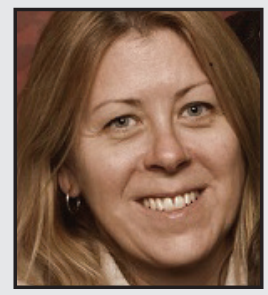

Kelly Young is an Associate Professor at Trent University's School of Education and Professional Learning where she teaches English curriculum methods and foundational courses. Her areas of research include language and literacy, curriculum theorizing, leadership in eco-justice environmental education, and arts-informed research. She has published articles in Language and Literacy: A Canadian Educational E- Journal (LLRC), Journal of Curriculum Theorizing (JCT), The EcoJustice Review: Educating for the Commons (EJR), and Journal of the Canadian Association for Curriculum Studies (JCACS). 